\title{
Nutritional profiling and value addition of products from Hypsizygus tessellatus
}

\author{
Garvita Chauhan', Shalinee Prasad ${ }^{2}$, Himanshi Rathore ${ }^{2}$, Satyawati Sharma ${ }^{2 *}$
}

${ }^{1}$ School of Biotechnology, Gautam Buddha University, Greater Noida, Uttar Pradesh, India, ${ }^{2}$ Centre for Rural Development and Technology, Indian Institute of Technology Delhi, Hauz Khas, New Delhi, India

Received: 07.12.2016

Accepted: 02.01.2017

Published: 10.02 .2017

*Address for correspondence:

Satyawati Sharma,

Centre for Rural

Development and

Technology, Indian Institute

of Technology Delhi, Hauz

Khas, New Delhi, India.

Email: satyawatis@hotmail. com

\begin{abstract}
Hypsizygus tessellatus is a popular wild edible culinary mushroom commonly cultivated in Japan, East Asia, and North Europe. It is rich in micronutrients and has great anti-tumorous, anti-cancerous rich polysaccharide fractions, i.e.,, $\beta$-glucan, thus making it a good source of nutraceuticals. This study was undertaken to investigate the nutritional as well as medicinal profile of this mushroom. Freeze dried and hot air dried samples were taken for the analysis. High-performance liquid chromatography - Refractive index detector investigations were carried out to estimate the content of $\beta$-glucan. The results revealed that it contains high proportions of protein $(33.89 \mathrm{~g} / 100 \mathrm{~g})$, fiber $(13.20 \mathrm{~g} / 100 \mathrm{~g})$, carbohydrates $(50.10 \mathrm{~g} / 100 \mathrm{~g})$, potassium $(1575 \mathrm{mg} / 100 \mathrm{~g})$, calcium $(98 \mathrm{mg} / 100 \mathrm{~g})$, and phosphorus ( $568 \mathrm{mg} / 100 \mathrm{~g})$. The fat content was found to be $2.80 \mathrm{~g} / 100 \mathrm{~g}$. Iron $(18 \mathrm{mg} / 100 \mathrm{~g})$ and zinc $(5 \mathrm{mg} / 100 \mathrm{~g})$ were present in trace amounts. Freeze dried fruit bodies showed better results than hot air dried samples pertaining to all nutritional and nutraceutical parameters. Value added products, i.e., biscuits and salted crackers were made by incorporating $5 \%$ and $10 \%$ mushroom powder in refined wheat flour and their proximate, organoleptic, and bioactive constituents were analyzed. Sensory evaluation based on hedonic scale resulted in high sensory ratings of all the products. This study suggested that incorporation of $5 \%$ mushroom powder in salted crackers (Mathri) and 10\% in biscuits not only increased concentration of protein, dietary fiber and $\beta$-glucan but also improved its flavor, texture, and acceptability.
\end{abstract}

KEY WORDS: $\beta$-glucan, biscuits, hot air drying, Hypsizygus tesellatus, lyophilization, salted cracker

\section{INTRODUCTION}

In the era of increasing population and shrinking land, secondary agricultural vocations are on their way wherein quality food supply can be anticipated. With the changing lifestyle and income, the demand for quality food and novel products has increased which are free of pesticides and harmful chemicals. The present century is leading toward a century of functional foods. Mushroom cultivation fits very well into this kind and might play pivotal role for ameliorating protein energy malnutrition. It is not only a source of food or an ingredient but also known to produce nutraceuticals, pharmaceuticals, and cosmeceuticals for the mankind due to the presence of a large amount of bioactive molecules in it. Surly, it can be the best therapeutic food in the coming days.

Hypsizygus tessellatus (Agaricales), popularly known as Shimeji, Bunashimeji and Hon-shimeji is one of the major temperate edible saprophytes from the family Tricholomataceae popularly found and consumed in East Asia, China, Japan, Korea, North. It is a popular industrialized culinary, medicinal mushroom known for its nutritional, organoleptic, and pharmacological characteristics (Barros et al., 2007). Due to its high protein, fiber, energy and low-fat content, it is an effective functional food for people having noncommunicable diseases (Mori et al., 2008). Along with good amount of minerals and vitamins, it also has high content of potassium and phosphorus in fruit body followed by magnesium, zinc, and copper. High amount of ergosterolprovitamin $\mathrm{D}_{2}$, riboflavin, biotin, and niacin are also present.

Bioactive polysaccharides from mushrooms consist of a $\beta$-linked glucose backbone having different patterns and degrees of branching. They have different chemical compositions, mostly belonging to the group of $\beta$-glucans having $\beta$ - $(1 \rightarrow 3)$ linkages as the main chain of glucan with additional $\beta$ - $(1 \rightarrow 6)$ branch points needed for their antitumor action. High molecular weight glucans are relatively more effective than low molecular weight. The 
polysaccharide $\beta$-(1-3)-D-glucan isolated from the cell wall of $H$. tessellatus, also known as biological response modifiers (Bohn and BeMiller, 1995) shows very high anti-cancerous activity along with anti-atherosclerotic and anti-oxidative effect (Mori et al., 2008; Akavia et al., 2009; Kang et al., 2013).

H. tessellatus is not commercially cultivated in India. Due to its high cost, it is not readily consumed. Moreover, since mushrooms are highly perishable, value addition is one novel way by which we can not only consume mushrooms but also preserve it for a longer time. In the recent years, there has been an increasing interest in "value added" agricultural products in the market. With so many fortified and value added products available in the market, inclusion of products made from mushrooms needs to be emphasized. Products such as assaulted crackers and biscuits are very popular among all age groups, especially with children. Biscuits hold a significant place in the baking industry due to variety in taste, texture, and aroma. They are low moisture foods with longer shelf life, generally prepared out of refined wheat flour, fat, and sugar. Biscuits enriched with protein, crude fiber, and minerals can be developed by partial supplementation of refined wheat flour with mushroom powder. Furthermore, salted crackers are an easy snack to be made at household levels.

In the wake of these facts, this study was undertaken to analyze the effect of drying, i.e., freeze drying and hot air drying on nutritional parameters and to study the scope of food fortification in ready to eat items like biscuits and salted crackers by this mushroom.

\section{MATERIALS AND METHODS}

\section{Sample Procurement and Preparation}

The fresh samples of $H$. tessellatus were procured from INA Market, Delhi (India). Samples were divided into two equal parts. One part was freeze-dried and the other was treated in hot air oven. Freeze drying of the samples was carried out in lyophilizer for $18 \mathrm{~h}$ at a temperature of $21^{\circ} \mathrm{C}$. Before drying in the lyophilizer, the mushrooms were cut into smaller pieces and kept in the refrigerator for $48 \mathrm{~h}$ at $-20^{\circ} \mathrm{C}$. For ht air oven drying; the mushrooms were dried at $60^{\circ} \mathrm{C}$ for $24 \mathrm{~h}$. The dried mushroom was grinded to fine powder for further analysis. The fresh sample was grounded into paste by mortar and immediately used for analysis.

\section{Proximate Analysis of Dried Mushrooms}

The fresh as well as the dried samples were analyzed for moisture, protein, fat, dietary fiber, ash and mineral contents
(AOAC, 2000). The crude protein content $(\mathrm{N} * 4.38)$ of the samples was estimated by the CHN (Elementar vario EL III) analyzer; the crude fat was determined by extracting a known weight of powdered mushroom sample with petroleum ether, using a Soxhlet apparatus; the ash content was determined by incineration at $550^{\circ} \mathrm{C}$. Total carbohydrates were calculated by difference. Total energy was calculated according to the following equations.

Energy $(\mathrm{kcal})=4 \times(\mathrm{g}$ protein $+\mathrm{g}$ carbohydrate $)+9 \times$ (g lipid);

Energy $(\mathrm{kJ})=17 \times(\mathrm{g}$ protein $+\mathrm{g}$ carbohydrate $)+37 \times$ (g lipid).

\section{Mineral Analysis}

Mushroom powder was digested by microwave digester and subjected to MP-AES (Agilent $4200 \mathrm{MP}-\mathrm{AES}$ ) for mineral analysis (Pardo et al., 2003). The content of phosphorus present in the samples was estimated by ultraviolet-visible spectrophotometer.

\section{Value Addition}

Fortified food products, salted crackers, and biscuits were made by standard protocol from the freeze-dried mushroom powder. Value addition was carried out at two levels $5 \%$ and $10 \%$ for both the products.

\section{Preparation of Salted Crackers}

Refined wheat flour with the other ingredients such as carom seeds, black pepper, cumin seeds, salt, and lukewarm ghee/oil were mixed in the bowl to make even dough. The dough was kept covered aside for $30 \mathrm{~min}$, and the salted crackers were deep fried in medium hot oil till it turned golden and crispy. The preparation of salted crackers involved the replacement of part of the refined wheat flour with $0 \%, 5 \%$ and $10 \%$ of mushroom powder. The $0 \%$ mushroom powder salted crackers was served as control (DMR Bulletin, 2008). The salted crackers were made on the same guidelines as prescribed for making mushroom cookies by DMR Solan, 2008.

\section{Preparation of Biscuits}

The flour blends were prepared by mixing predetermined portions of refined wheat flour and mushroom powder as required by the different formulations (Table 1) and kept separately. The preparation of the biscuits involved the replacement of part of the refined wheat flour with $0 \%$, 5\%, 10\% mushroom powder. The 100\% refined wheat flour biscuit served as the control (Eneche, 1999). 


\section{Sensory Evaluation of Value Added Products}

The sensory analysis of biscuits and salted crackers was done by 20 semi trained sensory panelists. The control items (biscuits and salted crackers) were made without mushroom. The sensory attributes evaluated for food products were aroma, color, flavor, appearance, mouth feel and overall acceptability. During sensory evaluation, panelists were instructed to drink water or rinse their mouth after each evaluation. Semi trained panelists were given a hedonic scale questionnaire to evaluate the value added product using a 9 point scale $(9$ - Extremely like, 8 - Like very much, 7 - Like moderately, 6 - Like slightly, 5 - Neither like nor dislike, 4 -Dislike slightly, 3 -Dislike moderately, 2 - Dislike very much and 1 - Extremely dislike) (Ranasalva and Visvanathan, 2014).

\section{Extraction of $\beta$-glucan}

Polysaccharide was extracted by microwave-assisted method. $5 \mathrm{~g}$ of dried mushroom powder and food product were accurately weighted and put into a baffled flask, $125 \mathrm{ml}$ of distill water was added. The flask was firstly heated for $8 \mathrm{~min}$ in a microwave oven $(540 \mathrm{~W})$ and then put into the magnetic water bath mixer $\left(600 \mathrm{r} / \mathrm{min}, 90^{\circ} \mathrm{C}\right)$ for $2 \mathrm{~h}$, the suspension was centrifuged and the sediment was extracted twice with the same method, supernatants of the three centrifuge were merged and concentrated at $50^{\circ} \mathrm{C}$ by evaporation under reduced pressure. Three volumes of ethanol were added for precipitation of polysaccharide at $4^{\circ} \mathrm{C}$ overnight; the precipitation was obtained by centrifugation $(5000 \mathrm{rpm}$, $10 \mathrm{~min}$ ) was repeatedly washed with ethanol. The extraction was repeated three times (Chen et al., 2013).

\section{Quantification of $\beta$-glucan}

Quantification of $\beta$-glucan content was done as per the process mentioned by Toledo (2013) with slight modifications.

\section{Statistical Analysis}

The data, collected in triplicates, have been expressed by its mean value and standard deviation. The results were subjected to one-way analysis of variance using SPSS 16.0. The significance of difference was determined according to Duncan's multiple range test. $P<0.05$ was considered to be statistically significant.

\section{RESULTS AND DISCUSSION}

Table 2 summarizes the results of proximate analysis of fresh wet sample, freeze dried sample and oven dried sample of the edible mushroom $H$. tessellatus. The fresh sample of mushroom had high moisture content of $92.6 \%$. After drying, i.e., by hot air drying and freeze drying, the moisture content was found to be $9.36 \%$ and $7.5 \%$, respectively. There was no significant difference $(P<0.05)$ in moisture content among the two drying techniques used but the results indicated that freeze drying is a better way to preserve mushroom due to low moisture content. Furthermore, it protects the nutritional quality significantly. The protein content in the fresh sample was $32.44 \mathrm{~g} / 100 \mathrm{~g}$, whereas it was found to be significantly lower in freeze dried $(29.5 \mathrm{~g} / 100 \mathrm{~g})$ and hot air oven dried sample $(28.67 \mathrm{~g} / 100 \mathrm{~g})$. This might be due to the enzymatic decomposition of protein during drying. The high loss of protein during hot air oven drying might be due to denaturation or change in solubility of protein at high temperature. The lipid and dietary fiber content was found to be $2.61 \mathrm{~g} / 100 \mathrm{~g}$ and $9.62 \mathrm{~g} / 100 \mathrm{~g}$, respectively, which were in agreement with the data reported by Kumar et al. (2013). The freeze dried sample retained higher lipid $(1.4 / 100 \mathrm{~g})$ and fiber content $(11.5 \mathrm{~g} / 100 \mathrm{~g})$ and lower ash content $(7.19 \mathrm{~g} / 100 \mathrm{~g})$ than the hot air oven dried sample. No significant differences were found in ash, carbohydrate, and energy content of fresh and dried sample. The carbohydrate and energy content was found

Table 1: Quantity of different ingredients of mushroom biscuits

\begin{tabular}{|c|c|c|c|c|c|c|c|}
\hline Sample & Refined wheat flour (g) & Mushroom powder (g) & Sugar (g) & Margarine (Fat) (g) & Baking powder (g) & Milk powder (g) & Vanilla essence $(\mathrm{ml})$ \\
\hline$T_{O B}$ & 100 & 0 & 30 & 45 & 1 & 5 & 3 \\
\hline $\mathrm{T}_{1 \mathrm{~B}}$ & 95 & 5 & 30 & 45 & 1 & 5 & 3 \\
\hline $\mathrm{T}_{2 \mathrm{~B}}$ & 90 & 10 & 30 & 45 & 1 & 5 & 3 \\
\hline
\end{tabular}

Table 2: Proximate composition ( $\mathrm{g} / 100 \mathrm{~g}$ edible weight) and energy value (kcal/100 g) of $H$. tessellatus

\begin{tabular}{|c|c|c|c|c|c|c|c|c|}
\hline \multirow[t]{2}{*}{ Sample } & \multicolumn{8}{|c|}{ Component } \\
\hline & Moisture (\%) & Protein (\%) & Fat/lipid (\%) & Ash (\%) & Dietary fiber (\%) & Carbohydrate (\%) & Energy (kcal/100 g) & $\boldsymbol{\beta}$-glucan (\%) \\
\hline Fresh (wet) sample & $92.63 \pm 0.31^{a}$ & $32.44 \pm 1.08^{a}$ & $2.61 \pm 0.20^{\mathrm{a}}$ & $9.62 \pm 1.22^{a}$ & $13.49 \pm 2.06^{\mathrm{a}}$ & $40.84 \pm 4.22^{\mathrm{a}}$ & $320.61 \pm 13.6^{a}$ & $13.11 \pm 0.1$ \\
\hline Hot air oven dried & $9.36 \pm 2.39^{b}$ & $28.67 \pm 1.22^{\mathrm{b}}$ & $0.94 \pm 0.20^{\mathrm{b}}$ & $7.45 \pm 2.28^{a}$ & $10.22 \pm 0.39^{a, b}$ & $43.37 \pm 6.20^{\mathrm{a}}$ & $296.62 \pm 20.5^{a}$ & $9.57 \pm 0.12$ \\
\hline Freeze dried & $7.5 \pm 0.6^{b}$ & $29.5 \pm 0.3^{b}$ & $1.4 \pm 0.8^{b}$ & $7.19 \pm 0.9^{a}$ & $11.5 \pm 1.6^{b}$ & $43 \pm 3.8^{\mathrm{a}}$ & $302.9 \pm 8.7^{a}$ & $11.62 \pm 0.2$ \\
\hline
\end{tabular}

Analytical data are means of triplicate analyses \pm SD. Means sharing a different superscript in each column are significantly different from each other $(P<0.05)$ using DMRT. DMRT: Duncan's multiple range test, SD: Standard deviation 
to be higher in hot air oven dried samples than the protein content. The possible reason behind the decrease of protein and increase of sugar content might be due to the release of amino acids from proteins during denaturation which when react with sugars to produce melanoidines by the Maillard reaction (Zhang et al., 2013).

Different drying methods resulted in significant variation in all the minerals estimated except zinc. The mineral contents of fresh and dried fruit bodies of this mushroom were found to be rich in potassium $(1574.7 \mathrm{mg} / 100 \mathrm{~g})$, phosphorus (568.3 mg/100 g), calcium (97.32 mg/100 g). The results were in agreement with the content reported by Mallikarjuna et al. (2013) and Okwulehie and Ogoke (2013) for Lentinus, Pleurotus, and Auricularias species. It was interesting to note that the lyophilized samples had lower amounts of minerals except for phosphorus and magnesium. The reason might be due to the prolonged exposure of mushroom for the lyophilization process. On the other hand, the oven dried samples showed higher minerals content due to its faster drying process that helps in retaining them. The contents of zinc were not significantly different between fresh wet mushroom and those dried by the two techniques. Iron and zinc were found to be in fairly good amounts (Table 3 ).

For value addition, lyophilized samples were used as they retained maximum nutrients. Furthermore, the $\beta$-glucan content (main bioactive compound) was higher in the freeze dried sample as compared to than the hot air dried sample. Table 4 shows the nutritional composition of value added products, i.e., salted crackers and biscuits. There was a significant increase in the protein content of both the products. Incorporating 10\% mushroom powder in salted crackers significantly increased the protein content (about 2\%), i.e., from $13.60 \%$ in control to $15.23 \%$ at $10 \%$ enrichment level. The protein content increased proportionally with the increasing mushroom powder level. Salted crackers containing 5\% mushroom powder significantly recorded the highest fiber $(5.69 \mathrm{~g} / 100 \mathrm{~g})$ and carbohydrates content $(58.47 \mathrm{~g} / 100 \mathrm{~g})$. These findings are in agreement with studies conducted by Singh and Chauha (1996) on the effect of utilization of defatted soy flour as a source of protein. The addition of 5\% and 10\% mushroom powder in salted crackers showed only noticeable effect on fat content (20.11\% and $19.48 \%$ ) compared with control $(18.14 \%)$. The increase in the fat content in food products might be due to deep frying (Table 4) indicating it as a good source of calorie for those suffering with protein-calorie malnutrition problems. No difference was found in the total ash and energy content which ranged between 2.14 to $2.37 \%$ and 459.59 to $470.98 \mathrm{kcal} / 100$ g respectively. Carbohydrates were among predominant macronutrients ranging from $56.02 \%$ to $63.18 \%$ (Table 4 ).

The results were similar to the previous studies done on effect of partial replacement of wheat flour with oyster mushroom (Pleurotus sajor-caju) powder on nutritional composition and sensory properties of biscuits by Wan Rosli et al. (2012). Biscuits containing 5\% mushroom powder significantly recorded the highest protein content $(17.33 \%)$. Addition of $5 \%$ and $10 \%$ mushroom powder did not affect the fat content (16.59-16.70\%). The ash content for the biscuits ranged from $0.79 \%$ to $1.41 \%$

Table 3: Minerals composition ( $\mathrm{mg} / 100 \mathrm{~g})$ of $H$. tessellatus

\begin{tabular}{|c|c|c|c|c|c|c|c|}
\hline \multirow[t]{2}{*}{ Sample } & \multicolumn{7}{|c|}{ Minerals } \\
\hline & $\mathrm{K}$ & $P$ & $\mathrm{Na}$ & $\mathrm{Mg}$ & $\mathrm{Ca}$ & $\mathrm{Fe}$ & $\mathrm{Zn}$ \\
\hline Fresh (wet) sample & $1574.7 \pm 1.35^{\mathrm{a}}$ & $568.37 \pm 0.67^{a}$ & $82.22 \pm 0.22^{\mathrm{a}}$ & $43.37 \pm 2.07^{c}$ & $97.32 \pm 1.24^{a}$ & $18.04 \pm 0.24^{a}$ & $5.84 \pm 1.03^{a}$ \\
\hline Hot air oven dried & $1562.59 \pm 1.95^{b}$ & $95.17 \pm 1.00^{\mathrm{b}}$ & $77.10 \pm 0.43^{b}$ & $33.87 \pm 0.10^{b}$ & $87.87 . \pm 2.00^{\mathrm{b}}$ & $14.25 \pm 1.01^{b}$ & $5.58 \pm 1.56^{a}$ \\
\hline Freeze dried & $1545.74 \pm 1.38^{c}$ & $105.60 \pm 0.54^{c}$ & $72.62 \pm 1.73^{c}$ & $39.44 \pm 0.91^{a}$ & $89.08 \pm 1.42^{b}$ & $12.50 \pm 0.34^{c}$ & $6.74 \pm 1.28^{a}$ \\
\hline
\end{tabular}

Analytical data are means of triplicate analyses \pm SD. Means sharing a different superscript in each column are significantly different from each other $(P<0.05)$ using DMRT. DMRT: Duncan's multiple range test, SD: Standard deviation

Table 4: Proximate composition ( $\mathrm{g} / 100 \mathrm{~g})$ and energy value $(\mathrm{kcal} / 100 \mathrm{~g})$ of value added products

\begin{tabular}{|c|c|c|c|c|c|c|c|}
\hline \multirow[t]{2}{*}{ Sample } & \multirow[t]{2}{*}{ Treatment } & \multicolumn{6}{|c|}{ Components } \\
\hline & & Protein & Fat/Lipid & Ash & Dietary fiber & Carbohydrate & Energy \\
\hline \multirow[t]{3}{*}{ Salted crackers } & $\mathrm{T}_{\mathrm{OM}}$ & $13.75 \pm 0.21^{\mathrm{a}}$ & $18.14 \pm 0.04^{a}$ & $2.37 \pm 0.53^{a}$ & $2.52 \pm 0.57^{a}$ & $63.18 \pm 1.08^{a}$ & $470.98 \pm 3.56^{a}$ \\
\hline & $\mathrm{T}_{1 \mathrm{M}}$ & $13.60 \pm 0.14^{b}$ & $19.48 \pm 0.34^{\mathrm{a}}$ & $2.44 \pm 0.23^{a}$ & $5.69 \pm 0.19^{b}$ & $58.47 \pm 2.43^{b}$ & $459.59 \pm 8.25^{a}$ \\
\hline & $\mathrm{T}_{2 \mathrm{M}}$ & $15.23 \pm 0.12^{b}$ & $20.11 \pm 0.83^{b}$ & $2.14 \pm 0.03^{a}$ & $4.83 \pm 0.05^{c}$ & $56.02 \pm 2.89^{b}$ & $467.38 \pm 10.2^{a}$ \\
\hline \multirow[t]{3}{*}{ Biscuits } & $\mathrm{T}_{O B}^{2 \mathrm{OB}}$ & $6.76 \pm 0.17^{\mathrm{a}}$ & $11.44 \pm 0.79^{a}$ & $0.79 \pm 0.09^{a}$ & $0.78 \pm 0.09^{a}$ & $80.23 \pm 0.68^{a}$ & $450.88 \pm 4.18^{a}$ \\
\hline & $\mathrm{T}_{1 \mathrm{~B}}$ & $17.33 \pm 0.27^{b}$ & $16.59 \pm 0.43^{a}$ & $1.41 \pm 0.32^{\mathrm{a}}$ & $0.86 \pm 0.01^{a, b}$ & $63.81 \pm 0.52^{b}$ & $473.86 \pm 1.56^{a}$ \\
\hline & $\mathrm{T}_{2 \mathrm{~B}}$ & $16.58 \pm 0.39^{c}$ & $16.70 \pm 0.15^{b}$ & $1.34 \pm 0.02^{b}$ & $0.92 \pm 0.06^{b}$ & $64.46 \pm 0.53^{b}$ & $474.48 \pm 0.90^{b}$ \\
\hline
\end{tabular}

Analytical data are means of triplicate analyses \pm SD. $\mathrm{T}_{0 \mathrm{M}}$ : Control; $\mathrm{T}_{1 \mathrm{M}}: 5 \%$ mushroom powder+95\% refined wheat flour; $\mathrm{T}_{2 \mathrm{M}}$ : $10 \%$ mushroom powder $+90 \%$ refined wheat flour (salted crackers). $T_{0 B}$ : Control; $T_{1 B}: 5 \%$ mushroom powder $+95 \%$ refined wheat flour; $T_{2 B}: 10 \%$ mushroom powder $+90 \%$ refined wheat flour (biscuits). Means sharing a different superscript in each column are significantly different from each other $(P<0.05)$ using DMRT. DMRT: Duncan's multiple range test, SD: Standard deviation 
Table 5: Minerals composition ( $\mathrm{mg} / 100 \mathrm{~g}$ ) of value added products

\begin{tabular}{|c|c|c|c|c|c|c|c|c|}
\hline \multirow[t]{2}{*}{ Sample } & \multirow[t]{2}{*}{ Treatment } & \multicolumn{7}{|c|}{ Minerals } \\
\hline & & K & $P$ & $\mathrm{Na}$ & $\mathrm{Mg}$ & $\mathrm{Ca}$ & $\mathrm{Fe}$ & $\mathrm{Zn}$ \\
\hline \multirow[t]{3}{*}{ Salted crackers } & $T_{O M}$ & $1492.37 \pm 0.17^{\mathrm{a}}$ & $82.12 \pm 0.96^{a}$ & $60.30 \pm 0.32^{a}$ & $34.31 \pm 1.13^{a}$ & $78.32 \pm 0.02^{a}$ & $5.35 \pm 0.02^{\mathrm{a}}$ & $2.10 \pm 0.02^{a}$ \\
\hline & $\mathrm{T}_{1 \mathrm{M}}$ & $1518.12 \pm 0.03^{b}$ & $89.34 \pm 0.78^{a}$ & $63.56 \pm 0.01^{\mathrm{a}}$ & $36.38 \pm 0.87^{a}$ & $83.98 \pm 0.56^{a}$ & $7.29 \pm 0.05^{b}$ & $2.75 \pm 0.03^{b}$ \\
\hline & $T_{2 M}$ & $1516.28 \pm 0.06^{c}$ & $89.09 \pm 0.08^{b}$ & $62.44 \pm 0.95^{b}$ & $36.81 \pm 0.05^{b}$ & $84.72 \pm 0.56^{b}$ & $7.53 \pm 0.02^{c}$ & $0.67 \pm 0.02^{c}$ \\
\hline \multirow[t]{3}{*}{ Biscuits } & $\mathrm{T}_{O B}^{2 \mathrm{M}}$ & $1529.83 \pm 0.02^{\mathrm{a}}$ & $78.15 \pm 0.01^{a}$ & $62.28 \pm 0.09^{a}$ & $32.57 \pm 1.94^{a}$ & $80.34 \pm 0.03^{a}$ & $6.33 \pm 0.11^{a}$ & $2.90 \pm 0.02^{a}$ \\
\hline & $T_{1 B}^{O B}$ & $1544.59 \pm 11.14^{\mathrm{ab}}$ & $92.20 \pm 0.02^{b}$ & $65.34 \pm 0.80^{a}$ & $34.76 \pm 0.08^{a b}$ & $81.49 \pm 0.06^{a}$ & $8.40 \pm 0.23^{b}$ & $3.94 \pm 0.04^{a}$ \\
\hline & $\mathrm{T}_{2 \mathrm{~B}}^{1 \mathrm{~B}}$ & $1537.09 \pm 0.07^{b}$ & $85.13 \pm 0.26^{c}$ & $64.68 \pm 1.30^{b}$ & $36.05 \pm 0.04^{b}$ & $81.41 \pm 0.54^{b}$ & $6.49 \pm 0.93^{b}$ & $3.86 \pm 0.14^{b}$ \\
\hline
\end{tabular}

Analytical data are means of triplicate analyses \pm SD. $T_{0 M}$ : Control; $T_{1 M}: 5 \%$ mushroom powder $+95 \%$ refined wheat flour; $T_{2 M}: 10 \%$ mushroom powder $+90 \%$ refined wheat flour (salted crackers). $T_{0 B}:$ Control; $T_{1 B}: 5 \%$ mushroom powder $+95 \%$ refined wheat flour; $T_{2 B}: 10 \%$ mushroom powder $+90 \%$ refined wheat flour (biscuits). Means sharing a different superscript in each column are significantly different from each other $(P<0.05)$ using DMRT. DMRT: Duncan's multiple range test, SD: Standard deviation

which was similar to the findings by Hooda and Jood (2005). Carbohydrates ranged from $63.81 \%$ to $80.23 \%$ indicating that the mushrooms are rich source of soluble sugars and fiber. These findings are in agreement with previous studies conducted by Eneche (1999) on biscuitmaking potential of millet/pigeon peaflour blends. Good amount of micro as well as macro minerals were found in both the products. High contents of potassium (1492.37-1518.12 mg/100 g), phosphorus (82.12$89.09 \mathrm{mg} / 100 \mathrm{~g})$, and calcium (78.32-84.72 mg/100 g) were found in salted crackers. The mineral content of biscuits prepared from refined wheat flour and mushroom powder resulted in significantly higher amount of potassium (1544.59 mg/100 g), phosphorus (92.20 mg/100 g), and calcium $(81.41 \mathrm{mg} / 100 \mathrm{~g})$. Iron and zinc were present in trace amounts in all the products and showed significant variation among the drying methods (Table 5).

$\beta$-glucan, the main active polysaccharide present in $H$. tessellatus has great pharmacological attributes. The estimation of $\beta$-glucan was done by high performance liquid chromatography - Refractive index detector. High $\beta$-glucan content was found $(6.96 \mathrm{~g} / 100 \mathrm{~g})$ in salted crackers with $10 \%$ mushroom powder incorporation (Table 6). However, in the case of biscuits also similar results were obtained at $10 \%$ value addition, i.e., $7.02 \mathrm{~g} / 100 \mathrm{~g}$. It is interesting to note that the content of $\beta$-glucan was almost negligible before incorporation with mushroom powder, i.e., in control only $2.11 \mathrm{~g} / 100 \mathrm{~g}$ was found in salted crackers and $1.86 \mathrm{~g} / 100 \mathrm{~g}$ was found in biscuits. Enhancement in $\beta$-glucan levels was observed after incorporating $5 \%$ and $10 \%$ mushroom powder. The higher temperature might have caused the degradation of $\beta$-glucan into low molecular weight fragments or may have depolymerized the linear structure thus changing its concentration and probably impairing its behavior (Oliveira et al., 2012).

Table 7 shows the sensory evaluation scores for salted crackers and biscuits. As the level of mushroom increased, the sensory scores for aroma, color, appearance and mouth feel of value added products varied. Replacement of refined wheat flour with $10 \%$ mushroom flour impaired the taste of salted crackers. Higher score for aroma, flavor and mouthfeel was recorded in salted crackers along with fortification of 5\% mushroom powder. Appearance of biscuits and salted crackers did not show a significant difference by adding different levels of mushroom flour. Biscuits fortified with $10 \%$ mushroom powder showed the best scores in flavor, color and mouthfeel and very highly acceptable.

\section{CONCLUSION}

Drying is one-way by which mushrooms can be preserved for a longer duration. Two different drying methods, freezedrying and hot air oven drying were applied to freshly harvested $H$.tessellatus mushroom. The proximate analysis revealed that even after drying these mushrooms, they proved to be a rich source of protein and fiber with high contents of potassium, phosphorus, and calcium. Sodium was found relatively less in its fruiting body thus indicating its excellent antihypertensive properties. $\beta$-glucan, the main active polysaccharide was also found in good amounts signifying its usefulness as nutraceutical food to cure deadly diseases like cancer and tumors. Value addition in products is one way by which we can encourage mushroom consumption among the population who preponderantly dependent on cereal diet. It was noticed that with an increase in the mushroom levels there was proportionate increase in the protein content as well. Furthermore, 10\% mushroom biscuits contained high amount of $\beta$-glucan as compared to mushroom salted crackers indicating the fact that baking does not reduce much $\beta$-glucan content and mushrooms can be effectively utilized in developing other ready to eat products. In a developing country like India, where malnutrition is a big problem, production of value added products of mushroom should be encouraged. They can be efficiently utilized to make other micronutrient/ protein rich snacks for the masses thereby popularizing mushrooms that are lesser known. 
Table 6: $\beta$-glucan content present ( $\mathrm{g} / 100 \mathrm{~g}$ of total dietary fiber) in value added products

\begin{tabular}{lc}
\hline Sample & $\beta$-glucan content \\
\hline$T_{O M}$ & $2.11 \pm 0.15$ \\
$T_{1 M}$ & $5.61 \pm 0.02$ \\
$T_{2 M}$ & $6.96 \pm 0.45$ \\
$T_{O B}$ & $1.86 \pm 0.44$ \\
$T_{1 B}$ & $6.62 \pm 0.12$ \\
$T_{2 B}$ & $7.02 \pm 0.28$ \\
\hline
\end{tabular}

Analytical data are means of triplicate analyses \pm standard deviation. $\mathrm{T}_{\text {om }}$ : Control; $\mathrm{T}_{1 \mathrm{M}}$ : $5 \%$ mushroom powder $+95 \%$ refined wheat flour;

$\mathrm{T}_{2 \mathrm{M}}: 10 \%$ mushroom powder $+90 \%$ refined wheat flour (salted crackers).

$\mathrm{T}_{\mathrm{OB}}$ : Control; $\mathrm{T}_{1 \mathrm{~B}}: 5 \%$ mushroom powder $+95 \%$ refined wheat flour;

$\mathrm{T}_{2 \mathrm{~B}}: 10 \%$ mushroom powder $+90 \%$ refined wheat flour (biscuits)

Table 7: Sensory attributes of mushroom biscuit and salted crackers as influenced by the addition of mushroom powder

\begin{tabular}{lllllll}
\hline Sensory attributes & \multicolumn{6}{l}{ Samples } \\
\cline { 2 - 7 } & $\mathrm{T}_{0 \mathrm{M}}$ & $\mathrm{T}_{1 \mathrm{M}}$ & $\mathrm{T}_{2 \mathrm{M}}$ & $\mathrm{T}_{0 \mathrm{~B}}$ & $\mathrm{~T}_{1 \mathrm{~B}}$ & $\mathrm{~T}_{2 \mathrm{~B}}$ \\
\hline Aroma & 7.2 & 8.1 & 7.8 & 7.3 & 7.7 & 7.8 \\
Color & 7.2 & 7.4 & 6.7 & 7.5 & 7.5 & 7.9 \\
Flavor & 7.5 & 7.9 & 7.2 & 7.3 & 7.8 & 8.1 \\
Appearance & 7.5 & 7.6 & 7.8 & 7.7 & 7.7 & 7.8 \\
M outh feel & 7.7 & 8.0 & 7.5 & 7.2 & 7.7 & 7.9 \\
Overall acceptability & 7.2 & 7.6 & 6.9 & 7.3 & 7.5 & 7.9 \\
\hline
\end{tabular}

Score $1=$ Dislike extremely and Score $9=$ Like extremely. $\mathrm{T}_{\mathrm{OM}}$ : Control; $\mathrm{T}_{1 \mathrm{M}}: 5 \%$ mushroom powder $+95 \%$ refined wheat flour; $\mathrm{T}_{2 \mathrm{M}}: 10 \%$ mushroom powder $+90 \%$ refined wheat flour (salted crackers).

$\mathrm{T}_{0 \mathrm{~B}}$ : Control; $\mathrm{T}_{1 \mathrm{~B}}: 5 \%$ mushroom powder $+95 \%$ refined wheat flour;

$\mathrm{T}_{2 \mathrm{~B}}: 10 \%$ mushroom powder $+90 \%$ refined wheat flour (biscuits)

\section{REFERENCES}

Akavia E, Beharav A, Wasser SP, Nevo E. Disposal of agroindustrial by-products by organic cultivation of the culinary and medicinal mushroom Hypsizygus marmoreus. Waste Manag 2009;29:1622-7.

AOAC. Official Methods of Analysis. $14^{\text {th }}$ ed. Washington, DC: AOAC; 2000.

Barros L, Baptista P, Correia D.M, Casal S, Oliveira B, Ferreira IC. Fatty acid and sugar compositions and nutritional value of five wild edible mushrooms from Northeast Portugal. Food Chem 2007;105:140-5.

Bohn JA, BeMiller JN. (1-3)- $\beta$-D-Glucans as biological response modifiers: A review of structure-functional activity relationships. Carbohydr Polym 1995;28:3-14.

Chen J, Lai P, Shen H, Zhen H, Fang R. Effect of extraction methods on polysaccharide of Clitocybe maxima stipe. Adv J Food Sci Technol 2013;5:370-3.

DMR Bulletin, Post Harvest Technology of Mushrooms, Solan; 2008; pp. 50-51.

Eneche EH. Biscuit-making potential of millet/pigeon pea flour blends. Plant Foods Hum Nutr 1999;54:21-7.
Hooda S, Jood S. Organoleptic and nutritional evaluation of wheat biscuits supplemented with untreated and treated fenugreek flour. Food Chem 2005;90:427-35.

Kang MG, Kim YH, Bolormaa Z, Kim MK, Seo GS, Lee JS. Characterization of an antihypertensive angiotensin I-converting enzyme inhibitory peptide from the edible mushroom Hypsizygus marmoreus. Biomed Res Int 2013;2013:283964.

Kumar A, Singh M, Singh G. Effect of different pretreatments on the quality of mushrooms during solar drying. J Food Sci Technol 2013;50:165-70.

Mallikarjuna SE, Ranjini A, Devendra HJ, Vijayalakshmi MR, Shashirekha MN, Rajarathnam S. Mineral composition of four edible mushrooms. J Chem 2013;2013:Article ID: 805284.

Mori K, Kobayash C, Tomita T, Inatomi S, Ikeda M. Antiatherosclerotic effect of the edible mushrooms Pleurotus eryngii (Eringi), Grifola frondosa (Maitake), and Hypsizygus marmoreus (Bunashimeji) in apolipoprotein E-deficient mice. Nutr Res 2008;28:335-42.

Okwulehie IC, Ogoke J. Bioactive, nutritional and heavy metal constituents of some edible mushrooms found in Abia State of Nigeria. Int J Appl Micro Biotech. Res 2013;1:7-15.

Oliveira LD, Oliveira M, MeneghettiVL, Mazzutti S, Colla LM, Elias MC, et al. Effect of drying temperature on quality of beta-glucan in white oat grains. Cien E Tecnol Alimentos 2012;32:793-7.

Pardo P, López-Sánchez JF, Rauret G. Relationship between phosphorus fractionation and major components in sediments using the SMT harmonised extraction procedure. Anal Bioanal Chem 2003;376:248-54.

Ranasalva N,Visvanathan R. Development of cookies and bread from cooked and fermented pearl millet flour. Afr J Food Sci 2014;8:330-6.

Singh R, Chauha GS. Effect of incorporation of defatted soy flour on the quality of biscuits. J Food SciTechnol 1996;33:355-7.

Toledo RC, Carvalho MA, Lima LC, Boas EV, Dias ES. Measurement of $\beta$-glucan and other nutritional characteristics in distinct strains of Agaricus subrufescens mushrooms. Afr J Biotechnol 2013;12:6203-9.

Wan Rosli WI, Nurhanan AR, Aishah MS. Effect of partial replacement of wheat flour with Oyster Mushroom (Pleurotus sajor-caju) powder on nutritional composition and sensory properties of butter biscuit. Sains Malays 2012;41:1565-70.

Zhang W, Niu X, Zhang W, Liu Z, Yuan S. The cultivation of Agaricus bisporus on the spent substrate of Flammulina velutipes. Afr J Agric Res 2013;8:4860-3. 